\title{
Medical Care and Protection of Confidentiality
}

\author{
Silvana B* \\ Faculty of Dental Medicine, University of Tirana Albania, Albania
}

*Corresponding author: Silvana Bara, Faculty of Dental Medicine, University of Tirana Albania, Albania,Email: silvana.bara@umed.edu.al

Abbreviations: CME: Code of Medical Ethics; AMA: American Medical Association; PEME: Principles of European Medical Ethics; ECMO: European Council of Medical Orders; ECOHR: European Court of Human rights; GMC: General Medical Council.

\section{Mini Review}

In a fast-evolving world, where information sharing has become part of our everyday life, the right to protect our lives, our identities, our work and our health has become very important. Privacy and personal data constitute an important aspect of private life and in medical settings their protection becomes even more important. Individuals in general, but health care providers too when they become patients, refuse or prefer not to share any information which they might thing could compromise their way of life, the behavior of other people towards them, they believe is embarrassing or might make them subject to discrimination. Patients may also avoid seeking medical care if they believe that their personal data will be easily accessed by anyone. While It is certain that at some point in our life we all need medical help, whether it is a visit to the doctor, medical or dental treatment, medication, mental help, etc. the protection of personal data in medical care becomes of paramount importance, benefiting not only the patient, but society as a whole. Every government's role is to protect the health and life of its citizens, where the protection of personal data forms part of the individual' private life. Without such protection public safety, national security or the economic well-being of the country are jeopardized.

\section{History of Medical Confidentiality}

Confidentiality is an important legal and ethical principle in medical care, deeply rooted in the history of mankind. It is first found in the Hippocratic Oath of 5-th century BC, which required medical practitioners to never divulge whatever seen or heard in the course of their profession and hold such information to be holy secrets. However, the requirement for physicians to maintain professional secrecy was also known in the later Roman Empire in the 4th century. Confidentiality as a principle was first mentioned in what has been considered as the first modern ethical code of medical ethics, published by Thomas Percival in 1803 Higgins GL, et al. [1].

Protection of confidentiality derives from the right to privacy (known as such in USA) or right to private life (as known in Europe). The right to privacy was first introduced in 1890 by two United States lawyers, Samuel D. Warren and Louis Brandeis, who described it as the "right to be left alone" Samuel D, et al. [2]. Such principle was further developed to also include the right to the protection of confidentiality of information and personal data. The privacy of the individual is highly prized in most societies and widely accepted as a civil right.

The importance of confidentiality in medical care was repeated in the Declaration of Geneva of 1948, adopted by the General Assembly of the World Medical Association (WMA) [3]. Even though the U.S. Constitution of the United States of America does not specify a "right to privacy", according to American jurisprudence such right is alluded to in the Fourth Amendment of the US Constitution, as well as the Bill of Rights (UMKC, 2020). Meanwhile, in 1950 in Europe [4], the European Convention on Human Rights, Article 8, provided for individual's right to private and family life [4]. Same protection was also included in the American Convention on Human Rights of 1969, Article 11 [5].

Privacy rights with respect to individual healthcare decisions and health information have been further outlined in court decisions, state statutes and legislation, professional codes of ethics and guidelines.

Good medical practice depends upon patients being able to discuss openly with the doctor the aspects of their health on the understanding that such details will be kept secret. 
It follows that any disclosure contrary to the individual's interest is also potentially detrimental to the public interest since it may discourage confiding in future. With no guarantee that their secrets will be protected, patients may withhold important information about their health care and also about the wellbeing of others etc. A particular aspect of medical confidentiality has to do with the question of "truth telling" Cipi B, et al. [6].

Trust is an essential part of doctor/healthcare providerpatient relationship. Trust in a doctor-patient relationship is something that involves both confidence and reliance. The patients are put in a vulnerable situation where they believe that the care-providers will care for their interest. For their own good, patients need to trust the doctors with their private information and body which is essential for their proper management. Trust in the medical field can be considered as either institutional trust or interpersonal trust. For healthcare system, interpersonal trust is built, sustained or damaged through face to face encounters with health care providers. As for the institutional trust, it is placed on the medical system or the institution. The doctor-patient interaction is influenced by both personality and social systems and trust occurs in a framework of interaction which is influenced by personality and social systems Chandra S, et al. [7].

Breaches of confidentiality in clinical practice due to carelessness, indiscretion, or sometimes even maliciously, jeopardize a duty inherent in the doctor-patient relationship. Confidentiality breaches can be related to the custody of clinical histories and records (admission forms, clinical and nursing report sheets, laboratory tests and other complementary examinations, and any other type of record containing patient data), as well as computer access to such records; to the consultation and/or disclosure of clinical and/or personal data to medical personnel not involved in the patient's clinical care, as well as people external to the hospital; or situations in which the improper disclosure of the patient's clinical data results from inadequate infrastructure, equipment, or poor organization of the hospital Cristina MBA, et al. [8]. Sometimes, such breaches can even be intentional, through p.ex. Disclosure of sensitive patient data to third parties, such as to pharmaceutical companies or companies dealing with analytics of patient data, etc.

Thus, governments have a duty to protect the principle of confidentiality in medical care. But, is this duty absolute? Should confidentiality be protected at any costs or are there limitations to such right?

\section{Disclosure of Patient Information}

World Health Organization considers health to be a state of complete physical, mental and social well-being and not merely the absence of disease or infirmity WHO [9].

According to the Code of Medical Ethics (CME) of the American Medical Association (AMA), patient privacy encompasses a number of aspects, including personal space (physical privacy), personal data (informational privacy), personal choices including cultural and religious affiliations (decisional privacy), and personal relationships with family members and other intimates (associational privacy). Patients need to be able to trust that physicians will protect information shared in confidence. Physicians in turn have an ethical obligation to preserve the confidentiality of information gathered in association with the care of the patient. In general, patients are entitled to decide whether and to whom their personal health information is disclosed. However, specific consent is not required in all situations. CME recognizes certain situations when information on the patient can be disclosed:

$>$ With the consent of the patient;

$>$ Without the consent of the patient. Such information can be shared to other health care personal for the purpose of providing care; to the authorities when such is required by law; to other third parties situated to mitigate the threat when in the physician's judgment there is a reasonable probability that the patient will seriously harm him/herself or the patient will inflict serious physical harm on an identifiable individual or individuals.

According to Article 7 of Principles of European Medical Ethics (PEME) of the European Council of Medical Orders (ECMO) the doctor must guarantee the complete secrecy of all the information collected and the findings made during his or her contact with the patient. The patient's death does not exempt the doctor from medical confidentiality. The doctor must respect the patient's privacy and take all necessary measures to render impossible the disclosure of all the information he or she has acquired while exercising his or her profession. If exceptions to medical confidentiality are provided for by national law, the doctor may ask for the prior opinion of his association or the professional body of similar competence CEOM [10].

While the provisions on medical confidentiality by the CME of the American Medical Association and the Principles of European Medical Ethics of the European Council of Medical Orders seem to give a general approach to such principle, the guidelines provided by United Kingdom's General Medical Council (GMC) seem more pragmatic. Apart from the cases provided by CME and PEME, GMC also recognizes cases where disclosure of patient information is ordered by a court or where such disclosure is justified in the public interest GMC [11]. 


\section{Annals of Bioethics \& Clinical Applications}

\section{Case-law on Medical Confidentiality}

Confidentiality in medical care has become such an important principle in medical care based also on the large case-law on the matter in all parts of the world. It must be stressed that medical law and ethics are becoming more and more important in medical care. In several cases the courts have opted for the protection of the confidentiality principle, in others for the protection of public interest.

In the case-law of the USA there are many cases on the protection or disclosure of patient information. Some of them are of particular importance with regard to patient confidentiality.

In Commonwealth v. Wiseman, 356 Mass. 251 [12] a filmmaker was sued for violating certain conditions he had agreed to in the filming of a state hospital. The court found that the First Amendment interest in having specialists in the fields of psychiatry and public health view the film was strong enough to outweigh patient privacy interest.

In Tarasoff v. Regents of the University of California, 17 Cal $3 \mathrm{~d} 425$ a therapist was held to have a duty to disclose private patient information to a third party in danger after his patient informed him of intention to murder a girl and then acted on it. Thus, public interest includes information that is relevant to public health or that is newsworthy and part of the public record.

In Doe v. Roe [13] the plaintiff sued her former psychiatrist, "Dr. Roe," over a book that chronicled the treatment of herself and her late husband. Although the patients' names were not included in the book and Dr. Roe had changed a number of facts, Doe argued that the inclusion of certain details revealed her identity to acquaintances. The New York Supreme Court held that Dr. Roe had entered into a contract with her patients to keep matters in confidence and had violated patient confidentiality with the publishing of her book.

In Jaffee v. Redmond, 518 U.S.1 [14], the Court ruled that confidential communications between a licensed psychotherapist and her patients in the course of diagnosis or treatment are protected from compelled disclosure.

In M.A.K. v. Rush-Presbyterian-St.-Luke's Medical Center, 316 Ill. App. 3d 156 [15], the plaintiff filed suit against the hospital, complaining of this release of information to an insurance company on the time spent by him on a rehabilitation from alcoholism program. He asserted that the physician-patient relationship had been violated, that his privacy had been invaded, and that there had been a negligent infliction of emotional distress. The circuit court granted the defendant hospital a judgment on the pleadings.

In the case-law of the European Court of Human Rights (ECOHR) there have also been several cases on the confidentiality of medical data, which the Court held that felt within the protection guaranteed by Article 8 of the European Convention on Human Rights (The Convention)"Private and family life".

In Z. v. Finland the applicant's ex-husband had been convicted of manslaughter for having knowingly exposed his victims to the risk of HIV infection. During the proceedings, despite her disapproval, the applicant's doctor and psychiatrist were called to give evidence about the applicant's medical condition. The national courts ordered that the full judgment, which mentioned the applicant's full name, and the case documents remain confidential for ten years. The Court found that the questioning of the applicant's medical advisers had been justified in the circumstances, since it was crucial in establishing when her former husband had become aware of his HIV infection and whether he was to be tried for manslaughter or a less serious offence. On the other hand, the Court found that a violation of Article 8 would occur if the applicant's medical data were made publicly accessible as early as ten years after her former husband's conviction. Observing that the applicant's medical data had become part of the criminal proceedings against her ex-husband without her consent, the decision to reveal the entire case-file so early on would not be supported by reasons which could be considered sufficient to override her interest in the data remaining confidential for a longer period.

In I. v. Finland the applicant, an HIV-positive nurse, suspected that unauthorized persons had accessed her medical records [16]. While the strict application of domestic law would have constituted a substantial safeguard in her case, the system at the hospital made it impossible to clarify retroactively the use of patient records or to determine whether information contained on the applicant and her family had been given to or accessed by unauthorized parties. Moreover, at the material time the records could also be read by staff not directly involved in her treatment. Although the hospital had subsequently taken ad hoc measures to protect the applicant against unauthorized disclosures by restricting access to treating personnel and registering her under a false name and social-security number, this had come too late. What had been required in the applicant's situation was practical and effective protection to exclude any possibility of unauthorized access occurring in the first place. The Court therefore found a violation of Article 8.

In Biriuk v. Lithuania [17] the applicants sued a newspaper for breach of privacy after it published a frontpage article quoting hospital staff as saying they were HIV 
positive. The article went on to give other details about their private life. Although the domestic courts found in the applicants' favor, they were unable to award more than the statutory maximum of EUR 2,900. The Court considered it crucial for domestic law to safeguard patient confidentiality and discourage any disclosures of personal data, especially bearing in mind the negative impact of such disclosures on the willingness of people at risk to take voluntary tests for HIV and seek treatment. In such cases of outrageous abuse of press freedom, the severe statutory limitations on judicial discretion in redressing the damage suffered thereby deterring recurrences had failed to provide the applicants with the protection of privacy they could have legitimately expected. There had thus been a violation of Article 8.

On the other hand, the Court has also acknowledged that the interests of a patient and the community as a whole in protecting the confidentiality of medical data may, in certain situations, be outweighed by the interests of investigating crime or of holding court proceedings in public.

In Avilkina and others v. Russia [18] a deputy prosecutor required medical institutions to report all refusals of a blood transfusion by Jehovah's Witnesses. As a result, he was informed of the second applicant's chemotherapy in a public hospital following a non-blood management treatment plan and of the fourth applicant's refusal of the use of foreign blood for surgical treatment. The Court observed that the applicants were not suspects or accused in any criminal proceedings and the prosecutor was merely conducting an investigation into the activities of a religious organization in response to complaints received by his office. There had consequently been no pressing social need to request the disclosure of the confidential medical information concerning the applicants. In fact, other options had been available to the prosecutor to follow up on the complaints, such as seeking the applicants' consent to disclosure or questioning them about the matter. The Court found a violation of Article 8 of the Convention.

\section{Conclusion}

The principle of confidentiality is of paramount importance in medical care. Respecting the confidentiality of health data is crucial not only for the protection of a patient's privacy but also for the maintenance of that person's confidence in the medical profession and in the health services in general as disclosure of confidential information given to the medical care providers, in the course of their duty to provide medical care, may seriously affect a person's private and family life, their social and employment situation, as well as the health and society as a whole. If such principle is not respected, life, liberty, freedom of movement can be jeopardized and as a result of this, social order and economic wellbeing as well.
As a conclusion, when discussing cases on whether patient information should be disclosed or not, each case is different and as such must be reviewed and decided bearing in mind its circumstances of the case and the possible consequences it might bring not only to the patient, but society too.

\section{References}

1. Higgins GL (1989) The History of Confidentiality in Medicine: the physician-patient relationship. Can Fam Physician 35: 921-926.

2. Samuel D, Brandeis LD (1890) The Right to Privacy. Harvard Law Review Publishing Association.

3. WMA International Code of Medical Ethics. Geneva. World Medical Association.

4. (1950) European on Human Rights, Council of Europe.

5. (1969) Commonwealth v. Wiseman, 356 Massachusetts Supreme Judicial Court.

6. Cipi B (2012) Ethical, juridical and historical aspects of medical Confidentiality. European Journal of Bioethics $3(9)$.

7. Chandra S, Mohammadnezhad M, Ward P (2018) Trust and Communication in a Doctor-Patient Relationship: A Literature Review. Journal of Healthcare Communications 3(3): 36.

8. Cristina MBA, Lopez EG, Chao EC, Barquero MMP, Villanueva MCM (2016) Confidentiality breaches in clinical practice: what happens in hospitals? BMC Medical Ethics 17(1): 52.

9. WHO (2020) WHO remains firmly committed to the principles set out in the preamble to the Constitution.

10. CEOM (2020) European Council of Medical Orders.

11. (2020) Genereal Medical Council of the United Kingdom.

12. (1969) Inter American Commission on Human Rights.

13. Doe v. Roe (1977) New York Supreme Court.

14. Jaffee v. Redmond, 518 US 1 (1996) Supreme Court of USA.

15. (2001) M.A.K., Appellee, v. Rush-Presbyterian-St.-Luke's Medical Center, Supreme Court of Illionois.

16. (2020) The Right of Privacy the Issue: Does the Constitution protect the right of privacy? If so, what aspects of privacy receive protection?. 


\section{Annals of Bioethics \& Clinical Applications}

17. Biriuk v. Lithuania (2018) Second Section, European Court of Human Rights.
18. Avilkina and others v Russia (2013) First Section, European Court of Human Rights.

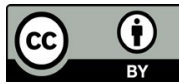

